\title{
FORMULAE FOR ZETA (odd)
}

\author{
EE. ZHOU and $\mathfrak{A l}$. ZHOU \\ 20220214
}

\begin{abstract}
There are the closed-form representations of the Euler's Zeta function at odd positive integers in this article.
\end{abstract}

The work to write down formulae for Euler's Zeta function at odd integers is still being sorted out and going to take some time, because this workload is huge, so the style of their expressions is first released on the sweet day.

Euler's Zeta function is defined as

$$
\left.\zeta(m)=\sum_{n=1}^{\infty} \frac{1}{n^{m}}, \quad \begin{array}{l}
n=1,2,3, \cdots \\
m=2,3, \cdots
\end{array}\right\} \in \mathbb{N} .
$$

For odd positive integers, their closed-form expressions or formulae should be,

$$
\zeta(2 k+1)=\pi^{2 k} \ln \left(2^{r_{1}} e^{r_{2}} 3^{r_{2}} \pi^{r_{4}}\right),
$$

where, 1) $k=1,2,3, \cdots \in \mathbb{N}$;

2) $r_{1}, r_{2}, r_{3}$ and $r_{4}$ are rational numbers which depend on $(2 k+1)$ and will be determined.

Although their closed-forms do not behave in the same way as Euler's zeta functions at even positive integers, from what little information we know, perhaps they are like this. They cannot help being born mysterious.

In addition, similar to the results of $\zeta(2 k+1)$, the following are formulas of Dirichlet Beta functions for even positive integers,

$$
\beta(2 k)=\pi^{2 k-1} \ln \left(2^{r_{1}} e^{r_{2}} 3^{r_{2}} \pi^{r_{4}}\right) .
$$

E. ZHOU, UC Berkeley.

ftl. ZHOU, TJ. pdebox@yahoo.com 
说明: 前一页为贝塔 (双) 和泽塔 (单) 的精确解 (形式) 结果, 它们曾于 2020 年在某公共信 息范围间接展露过, 因工作量巨大, 后续研究一直在间断中进行, 想必推布其所以然之时尚 早, ……, 还是先睹为享舒乐。另外, 提供述曰诸多特禀念纪之词为辅:

\section{《卜算子》}

與 Beta 雙和 Zeta 單 算卜

2020

從未顯神幽,

還是奇輪偶。

倒幕級和似易得,

哪想折磨多。

門錀何全有?

非要文稿厚?

息少條缺律理赢,

超算須來秀! 